\title{
PERAN MAHASISWA SEBAGAI MASYARAKAT DALAM MENANGKAL ISU HOAX DI TAHUN POLITIK
}

\author{
Oleh: M. Jamil ${ }^{1}$
}

Akhir-akhir ini suasana bangsa Indonesia kian hari kian memanas, salah satu penyebabnya adalah kini Indonesia memasuki tahun politik. Tahun 2018 Pilkada Serentak. Tahun 2019 pemilihan anggota DPR, DPD, DPRD provinsi, dan DPRD kabupaten/kota serta pencalonan presiden dan wakil presiden.

Dalam lampiran Peraturan Komisi Pemilihan Umum (KPU) Nomor 1 Tahun 2017 disebutkan, kegiatan sosialisasi kepada masyarakat sudah dimulai sejak pada 14 Juni 2017 dan pemungutan dan penghitungan suara Pilkada Serentak 2018 akan dilaksanakan pada 27 Juni 2018.

Sedangkan tahapan jadwal penyelenggaraan Pemilu 2019 yang dirilis KPU untuk pemilihan anggota DPR, DPD, DPRD provinsi, dan DPRD kabupaten/kota serta pencalonan presiden dan wakil presiden yakni, 1 Agustus 2017-28 Februari 2019 penyusunan peraturan KPU. 26 Maret 2018-21 September 2018 pencalonan. 23 September 2018-13 April 2019 masa kampanye. 14 April 2019-16 April 2019 masa tenang. 8 April 2019-17 April 2019 pemungutan dan penghitungan suara. Juli-September 2019 peresmian keanggotaan. Agustus-Oktober 2019 pengucapan sumpah/janji.

Dalam suasana tahun politik ini, tidak jarang ditemukan isu-isu yang seksi yang ditampakkan di khalayak publik. Dari adu dan penawaran program yang pro rakyat, saling serang dan cari kesalahan lawan politik, bahkan tidak jarang ada juga yang menyebarkan hoax untuk kepentingan politiknya.

\footnotetext{
${ }^{1}$ Ketua Umum Pusat Studi Mahasiswa Pascasarjana (PUSMAJA) Mbojo-Yogyakarta Periode 2015-2017 | | Ketua II Bagian Eksternal Dewan Pimpinan Cabang Perhimpunan Mahasiswa Hukum Indonesia Daerah Istimewa Yogyakarta (DPC PERMAHI DIY) Periode 2012-2014 | Email: jamilncera@gmail.com | FB/Youtube/IG/Twitter: @MJAMILSH | Website: http://www.mjamil.my.id.
} 


\section{Peran Mahasiswa sebagai Masyarakat dalam Menangkal Isu Hoax di Tahun Politik}

Kita sebagai masyarakat ${ }^{2}$, lebih-lebih sebagai pemuda terpelajar (Mahasiswa $^{3}$ ) harus mengambil bagian untuk melakukan sesuatu perubahan positif dalam masyarakat, salahsatunya dalam menangkal hoax yang tersebar luar di masyarakat. Biar bagaimana pun, peran mahasiswa dalam menangkal hoax di tahun politik ini sangat diharapkan, karena karakter mahasiswa yang sejatinya masih murni dari kendali atau pengaruh siapapun (independent). Mahasiswa harus berperan aktif membantu mengawas dan mengontrol berjalannya Pemilu agar terbebas dari hal-hal yang yang tidak kita inginkan, seperti penyebaran ujaran kebencian, hoax, dan hal-hal lainnya yang bertentangan dengan peraturan perundang-undangan yang berlaku di Indonesia.

Dengan kemurnian pikiran yang disandang oleh mahasiswa, diharapkan ketika hadir di tengah-tengah masyarakat menjadi benar-benar sebagai agen perubahan (agent of change), jangan malah menjadi bagian dalam penyebaran hox dan ujaran kebencian tersebut.

\section{Peran Masyarakat Umum di Tahun Politik}

Hidup dan kehidupan dalam bermasyarakat syarat akan nilai kebersamaan, itulah sejatinya hidup dalam bermasyarakat yang telah menjadi tradisi dari masa ke masa sejak ribuan tahun silam, yang mana kebersamaan tersebut dibuktikan dengan adanya nilai-nilai yang tertanam dalam pribadi-pribadi masyarakat,

\footnotetext{
${ }^{2}$ Masyarakat merupakan sekelompok orang yang membentuk sebuah sistem semi tertutup (atau semi terbuka), di mana sebagian besar interaksi adalah antara individu-individu yang berada dalam kelompok tersebut. Kata "masyarakat" sendiri berakar dari kata dalam bahasa Arab, musyarak. Lebih abstraknya, sebuah masyarakat adalah suatu jaringan hubungan-hubungan antar entitasentitas. Masyarakat adalah sebuah komunitas yang interdependen (saling tergantung satu sama lain). Umumnya, istilah masyarakat digunakan untuk mengacu sekelompok orang yang hidup bersama dalam satu komunitas yang teratur. Lihat Wikipedia, "Masyarakat", https://id.wikipedia.org, Diakses 19 April 2018.

${ }^{3}$ Sarwono (1978) memberi gambaran bahwa mahasiswa merupakan setiap orang yang secara resmi telah terdaftar untuk mengikuti pelajaran di perguruan tinggi. Mahasiswa adalah suatu kelompok dalam masyarakat yang memperoleh status karena memiliki ikatan dengan perguruan tinggi. Mahasiswa juga merupakan seorang calon intelektual ataupun cendekiawan muda dalam suatu lapisan masyarakat yang sering kali syarat dengan berbagai predikat dalam masyarakat itu sendiri. Shelvi Sianturi, "Mahasiswa", https://masukuniversitas.com, Diakses 19 April 2018.
} 
diantaranya seperti gotong royong, musyawarah mufakat, dan lain sebagainya. Sikap kebersamaan (kolektifitas) tersebut juga harus terpartri dalam mensukseskan tahun politik, karena tahun ini (2017) dan tahun depan (2018) kita sudah dihadapkan dengan Pemilu yang akan menyita lebih dalam daya kepekaan kita dalam memilih pemimpin atau wakil rakyat, karena hasilnya tersebut akan menentukan perubahan bangsa ini untuk 5 tahun selanjutnya. Maka oleh karena itu, semua lapisan masyarakat harus berperan aktif untuk mensukseskannya, yang bisa dilakukan masyarakat adalah ketika para calon kepala daerah/caleg/capres turun di masyarakat mengubarkan janji-janji manisnya, maka masyarakat harus jeli dan cerdas dalam menyikapinya, jangan sampai orang yang di pilih tidak mewakili aspirasi-aspirasi masyarakat hingga sebaliknya yang terjadi kelak bila telah terpilih malah menyimpangi dari tanggungjawab yang harus diembannya. Bila mana dalam lapangan ada yang melakukan penyuapan di masyarakat, yakin dan percayalah, orang-orang semacam itu tidak akan sepenuhnya mau melaksanakan apa yang menjadi kewajibannya bila kelak telah terpilih. Karena ketika telah terpilih yang paling pertama dia pikirkan adalah, bagaimana caranya untuk mengembalikan uang-uang yang telah mereka keluarkan, dan dengan kewenangannya yang besar, mereka bisa dengan leluasa memanfaatkannya untuk menggunakan dana yang seharusnya untuk kepentingan masyarakat digunakan sepenuhnya untuk pribadinya, agar uang yang dia keluarkan semasa kampanye cepat kembali dan bahkan mengambil sebanyak-banyaknya untuk memperkaya dirinya dan keluarganya.

\section{Peran Mahasiswa dalam Menyambut Tahun Politik}

Mahasiswa merupakan agen pengontrol sosial (agents of social control) dan agen perubahan (agent of change), yang mana ditangan mahasiswa bisa membuat atau menciptakan suatu perubahan dalam suatu lingkup masyarakat, bangsa, Negara, bahkan dunia. Karena dengan sifat dan karakter mahasiswa yang sejatinya masih murni dari kendali atau pengaruh siapapun (independent), dengan kemurnian hati dan pikiran seorang mahasiswa bisa merangkul dari aspirasi semua kalangan, lebih-lebih untuk kepentingan masyarakat menengah kebawan. 
Seperti selogan yang pernah digembar-gemborkan oleh sang pendiri bangsa (funding father) kita yaitu Soekarno, tentang besarnya pengaruh pemuda/mahasiswa bila mereka bersatu, beliau pernah mengatakan dengan lantang "berikan saya sepuluh pemuda, maka saya akan bisa mengguncangkan dunia", itulah sejatinya prestasi yang akan diraih oleh pemuda/mahasiswa bila mana mereka menyatukan ide, pikiran, gagasan, dan bersama-sama melangkah melakukan perubahan untuk masyarakat, bangsa dan Negara tercinta ini, maka suatu perubahan yang nyata akan terlihat atau terpampang dengan jelas dari buah tangan atau karya pemuda/mahasiswa.

Sejatinya kita semua harus menyatu dengan indah seperti halnya lidi-lidi yang berserakan dikumpulkan jadi satu, membentuk satu kekuatan yang utuh, yaitu kekuatan untuk membangun suatu masyarakat, bangsa dan Negara. Karena seberapa besarpun suatu persoalan kalau dikerjakan secara bersama maka akan terasa mudah, begitu juga sebaliknya, sesederhana apa pun suatu pekerjaan kalau dikerjakan sendirian akan terasa sulit adanya, seperti halnya sapu lidi, sapu lidi merupakan gabungan dari puluhan atau ratusan lidi, bila satu lidi ingin menyapu batu yang besarnya sebesar genggam tangan maka lidi tersebut tidak akan bisa menyapu batu itu, begitu juga sebaliknya, bila mana lidi-lidi tersebut digabungkan jadi satu dalam satu ikatan akan menjadi sapu lidi dan juga akan bisa menyapu batu yang besarnya sebesar genggaman tangan tersebut. Oleh karena itu, makna atau hasil yang didapat dari suatu kebersamaan itu akan bernilai tinggi adanya. Itulah sikap-sikap kolektifitas yang harus tertanam dalam hidup dan kehidupan dalam suatu masyarakat, bangsa dan Negara, yang mana bila kita ingin menggapai tujuan yang mulia sejatinya kita harus melaksakan tujuan tersebut secara bersamasama biar suatu persoalan sesulit apapun bisa dilakukan atau disa dipecahkan secara bersama-sama. Begitu juga apabila kita semua ingin mensukseskan dan turut andil dalam menjaga keharmonisan tahun politik, kita harus bahu membahu membentuk satu kekuatan yang utuh untuk mensukseskannya.

Wallahu a'lam bish-shawabi. 
"Peran Mahasiswa Sebagai Masyarakat Dalam Menangkal Isu Hoax Di Tahun Politik"

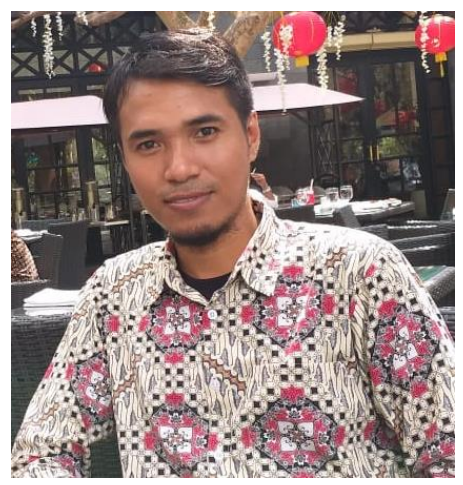

Penulis: M. Jamil, S.H.

Ketua Umum Pusat Studi Mahasiswa Pascasarjana (PUSMAJA) Mbojo-Yogyakarta Periode 2015-2017 | Ketua II Bagian Eksternal Dewan Pimpinan Cabang Perhimpunan Mahasiswa Hukum Indonesia Daerah Istimewa Yogyakarta (DPC PERMAHI DIY) Periode 2012-2014 | Ketua Ikatan Keluarga Alumni Prodi Ilmu Hukum Fakultas Syariah dan Hukum UIN SunanKalijaga Yogyakarta (IKASUKA Ilmu Hukum) Periode 2018-2023

\section{Ful Sumber Tulisan:}

M. Jamil, "Peran Mahasiswa Sebagai Masyarakat Dalam Menangkal Isu Hoax Di

Tahun Politik", dimuat di Opini PEWARTA-NEWS.COM dan Kolom IKASUKAIH.UIN-SUKA.AC.ID, pada 20 April 2018. 